\title{
Accessibility of flood risk insurance in the uk - confusion, competition and complacency
}

\author{
ABSTRACT \\ Flood risk insurance can be an effective tool in assisting the restoration of damaged \\ property after a flood event and sustaining communities through difficult times. It can \\ also form part of a wider flood risk management strategy. In the light of recent flood \\ events in the UK and in the context of changing property insurance markets the universal \\ cover previously enjoyed by floodplain residents has been called into question. \\ Conflicting media and industry views leave the floodplain resident and the wider \\ community in confusion. A survey of floodplain residents in England regarding their \\ experience with flooding and flood insurance in England has been undertaken. The \\ results reveal that some floodplain residents do indeed encounter difficulties when \\ seeking insurance for their homes. However, despite the risk averse policies of some \\ insurers, availability of insurance is still strong in both at risk and previously flooded \\ locations which may lead to complacency among residents. As a tool in risk \\ management therefore the competitive market is hampered by homeowners search \\ strategies and lack of information from realizing its potential.
}

Keywords : flood; risk; management; insurance; search; adaptation

\section{J.E. Lamond, Professor D.G. Proverbs and Dr F.N. Hammond \\ School of Engineering and the Built Environment, University of Wolverhampton, Wolverhampton, $U K$}

\section{Address for Correspondence}

Jessica Lamond

Senior Research Fellow

Centre for Floods Communities and Resilience

Faculty of Environment and Technology

University of the West of England

Frenchay Campus

Coldharbour Lane

Bristol BS16 1QY

jessica.lamond@uwe.ac.uk

Tel 01173283268

Mob 07824694792 


\section{Introduction}

Victims of flooding experience a frightening and stressful chain of events which can leave effects many years after the waters recede (Gruntfest, 1995, Hajat et al., 2003, EA/DEFRA, 2005). Among the most distressing of post-flood impacts is the physical displacement from home and community particularly if alternative accommodation is far removed (Samwinga et al., 2004). Factors facilitating a quick reinstatement of flooded property will therefore assist victims in their recovery and can also help in maintaining community cohesion. In the ideal scenario flood victims would welcome secure and timely financial support for the recovery work as well as ready access to professionals experienced in the restoration of flood damaged buildings. An effective insurance market can provide both of these things.

Insurance against flood damage can also provide a benefit to the wider community in preventing blight, sustaining the local community and providing employment during the reinstatement process for tradespersons and buildings suppliers. The presence of insurance is not an unalloyed good however, as has been extensively described by Kunreuther (1974), Clark et al (2002) and Crichton(2005), among others. Insurance can induce moral hazards in those able to prevent flood damage if it removes the incentive to do so. Recently authors have argued that, if this danger is recognized, it may be possible for insurers to take steps to prevent complacency amongst property stakeholders (Huber, 2004, Green and Penning-Rowsell, 2004).

In the UK, private flood insurance is the main source of funding for the reinstatement of flooded residential property. There is no state provision for flood reinstatement and, as part of an agreement between the Association of British Insurers (ABI) and the UK Government, flood cover is included as standard in domestic property insurance contracts (Huber, 2004, Crichton, 2005). However in the light of the high costs of recent flooding events and the generally accepted view that flood events in the UK are becoming more frequent and are likely to continue to do so (Dlugolecki, 2004, Environment Agency, 2004, ABI, 2005b) insurers are becoming less willing to cover properties at risk of flooding (Green and Penning-Rowsell, 2004, Crichton, 2005). Contrasting views are presented by the media, with much attention on the difficulties experienced by homeowners seeking cover (Downes, 2005, Dey, 2006, Stevenson, 2002, Jones, 2003), and the Association of British Insurers (ABI) who state that there is a reasonable market for flood insurance available (ABI, 2005d, ABI, 2005c). 
The survey described in this paper was designed to increase the understanding of the flood insurance market from the consumer's point of view and to assess the barriers to insurance for the floodplain resident in the UK. The questionnaire directly addressed issues such as the increased difficulties encountered whilst seeking cover and the strategies employed by homeowners to gain affordable insurance including resilience and flood exclusion. It was not designed to reverse engineer a model of underwriting decisions because insurers will be using different factors to price premiums many of them unrelated to flood risk. Rather the aim was to determine whether flood risk was the dominant factor in determining availability and cost of insurance in flood risk areas. Further the questionnaire sought to gain insight into the reaction of the floodplain resident to these anticipated difficulties in respect of whether mitigation activities were fostered by the emerging regime. In addition it was hoped to assess whether insurance problems were sufficiently severe to deter potential purchasers of floodplain property and therefore whether insurance cost and availability could be acting as a widespread trigger to reduce property value in the floodplain.

This study is based in the UK which has a unique insurance market and provides valuable empirical evidence about the current state of the UK market for flood insurance. However the findings are pertinent elsewhere where private companies or government agencies are providing flood cover addressing as it does the perceptions of risk and strategies adopted by homeowners in flood risk areas. If the climate continues to change and bring with the change increased flooding events the pressure on insurance and re-insurance regimes may lead to greater reliance on private insurance cover and thus to further exclusions of flood risk residents from flood cover worldwide.

\section{The Changing Market for Insurance in the UK}

The historical agreement between the ABI and UK Government has come under scrutiny in recent years, particularly following the widespread flooding across the UK in spring 1998 and autumn 2000. Widespread flooding in summer 2007 has revived the debate. The question of moral hazard was raised regarding the failure of the Government to maintain flood defences and of homeowners to take responsibility for flood risk (Clark et al., 2002). The insurance community threatened to remove cover for property at risk of flooding (Brown, 2001, Stevenson, 2002, Dey, 2006). A great deal of new government spending on flood defences and flood risk management has 
ensued (Environment Agency, 2001, Fleming, 2001). There has also been a renewal of the commitment by insurers to cover all but the most at risk. However this renewed commitment, known as the "statement of principles" (ABI, 2005a, ABI, 2002) renders it acceptable for insurers to refuse to issue a policy to any homeowner with a probability of flooding greater than 0.013 or once in 75 years if there are no plans to improve defences in their area. The ABI estimates that this encompasses 280,000 homes in the UK (ABI, 2005c).

Recent changes in insurance practices in the UK market have also contributed to the ability of insurers to price home insurance policies based on risk. There has been a general shift away from the bundling of insurance into mortgages and towards the tendency for residents to shop around for a policy (Lamond et al., 2006). This tendency has probably contributed to a holding down of average insurance rates, despite rising claims, because low cost insurers can cherry pick low risk customers and offer policies at a much reduced rate (Clark et al., 2002). The rise of the internet and price comparison websites may well accelerate that trend (Lamond et al., 2006). The profitability of the domestic property insurance market could be threatened with traditional insurers left as an insurer of last resort for high risk property. Insurers have a duty to their shareholders to address these profitability issues via increased premiums or reduced risk exposure.

The ability to identify the flood risk for a particular property has also been improved in recent years through improved flood risk mapping. The Environment Agency publishes flood risk maps on their website which are suitable for giving general guidance to the public (EA, 2006). They define four levels of flood risk, significant, moderate, low and outside the floodplain. These levels correspond to probabilities of flooding of $1.3 \%$ and above, $0.5 \%$ and above $0.1 \%$ and above and below $0.1 \%$ respectively. The Environment Agency states, however that their maps are not sufficient to assign risk to individual properties. More detailed information is available to insurers however and individual insurance companies have taken steps to improve on Environment Agency estimates (Crichton, 2005). For example the Norwich Union commissioned an elevation map of the country and subdivided the significant flood frequency band to give finer estimates of flood risk. Another method of establishing the risk of flooding for individual properties is to request an assessment from the Environment Agency in the form of a letter, for which they levy a charge. Additionally a homeowner can commission a survey of flood risk from an 
independent source in an attempt to establish their flood status. It is not clear from published sources exactly how insurers are using that information to manage their flood risk portfolio.

The flood risk mapping noted above refers only to coastal and fluvial flooding and ignores the increasing incidence of overland flow due to inadequate drainage and infrastructure failure which follows less predictable patterns. Insurance of such risks should therefore not be subject to increased premiums unless frequent flood claims alert the insurer to a high risk profile. This sort of flooding is not within the remit of the current study.

Insurers were criticised in the delivery of their claims handling in the aftermath of the 1998 floods (Warwickshire Trading Standards, 1998) and also by analysts of the impact of earlier floods in Towyn, North Wales (Welsh Consumer Council, 1992). The benchmarking of repairs of flood damaged property and the customer satisfaction with their outcome has been studied by Soetanto et al (2002) and Samwinga et al (2004). Lessons have been learned and implemented but there is still a wide variation in the performance of the best and the worst reinstatement practices as experienced in Carlisle after the January 2005 flood (Hendy, 2006). There is also little evidence that the best interests of consumers are being served in the process of underwriting with some insurers refusing to cover flood risk postcodes (Stevenson, 2002, Which?, 2005) and others pricing customers out of the market.

In this era of growing concern it is important to consider where this confusion leaves the flood risk resident and how this will impact on their tendency to buy insurance or to protect themselves in other ways from the risk of flooding.

\section{Research Context}

The behaviour of populations in the presence of risk has been the subject of study by Ehrlich and Becker (1972). They suggest that self-insurance behaviour, such as perhaps installing resilient fittings to reduce the cost of damage, is used as a substitute for market insurance. For rare events, there is a tendency to rely on market insurance rather than self-insurance because market premiums will be related to risk whereas expenditure on self-insurance is unrelated to risk. An obvious exception to this is selfinsurance behaviour which can be taken at the point of imminent flooding such as moving items out of harms way. However, self-protection behaviour, such as fitting door and air brick guards to prevent the ingress of water can be complementary to 
market insurance if the premium setting regime reflects the reduced probability of damage. In other words, the availability of properly priced insurance can encourage responsible behaviour in floodplain residents but is most likely to result in selfprotection rather than self-insuring behaviour. The role of the insurer as incentive for mitigation has been identified by Arnell et al (1984), however the information required for realistic risk based pricing incorporating mitigation activities is still lacking.

The UK flood insurance market is unusual in forming part of the standard domestic policy provided by private insurance companies. For most home buyers there is no choice over whether or not to purchase flood cover for the fabric of the building because gaining insurance will be a required condition of their mortgage agreement. This fact makes it difficult to apply international research or theories of risk avoidance behaviour directly. If insurance is more or less a default position then policyholders are unlikely to consider the advantages to them of other avoidance strategies. In a competitive market, the incentive for insurers to invest in long term damage avoidance is also lacking due to the tendency of policyholders to switch insurance provider.

Those residents with experience of flooding may appreciate the gap between cover provided by insurance and the costs, stress and inconvenience of flood damage but in advance of flooding this gap may be perceived as small. Moral hazard will exist unless insurers offer assistance or incentives for damage avoidance. Where insurance costs increase or cover is withdrawn a policyholder may seek alternative strategies to manage flood risk. If insurers are acting in a concerted manner this may leave floodplain residents at risk but may also motivate them to take responsible actions.

In the US where flood insurance is government backed there has been research looking at the take up of insurance policies (Browne and Hoyt, 2000, Burby, 2001, Kriesel and Landry, 2004) and the link between insurance cost and property value has been explored by Macdonald et al (1987) and Shilling et al (1989). However, in the US there is no issue about insurance availability and the cost is predetermined and known to all parties. Thieken et al (2006) considered the motivation to insure and pursue mitigating actions against flooding in Germany but without reference to availability or cost. There are some common findings notably the complacency with which flood risk is treated by many floodplain residents and the lack of flood mitigation activity undertaken by the majority. 
In the changing UK market the strategies of residents facing a shortfall in insurance cover may reveal insights into their attitudes to risk and their role in management of risk.

\section{Research Methodology}

The methodology employed by this study was designed to canvass the opinion and experience of floodplain residents. A self-administered postal questionnaire was selected as the most cost effective delivery mechanism for the survey. The data were analysed (In SPSS) both in terms of the distribution of variables of interest and the correlations between key variables.

\subsection{Survey Instrument}

The questionnaire was designed for maximum ease of response consisting mainly of categorical closed questions requiring ticks in the relevant boxes. Questions were designed after examining the information collected by insurance companies on their websites and in consultation with industry experts. Sections on property details, flood experience, insurance held, costs and claims history, selection mechanism and difficulties encountered whilst searching for insurance were included. A final free text section allowed respondents to proffer further details or explanations about flood and insurance history. Personal information was not collected apart from respondent age.

\subsection{Sample selection}

The target population was households in the floodplain, at all three levels of flood risk with a control group of households not in the floodplain. In addition households with differing flood histories were desired, flooded and not flooded within each risk category where possible. The population of households in the floodplain is unknown and its characteristics remain unmeasured. Environment Agency lists of properties in the floodplain are not generally available to researchers and lists of which properties actually flooded are not compiled. Structured sampling techniques on national databases were therefore inappropriate and a pragmatic approach had to be taken. Samples from four study sites (Southsea, Shrewsbury, Malton and West Bridgford) were chosen from addresses taken from the council tax register. Their flood histories are described below and their geographical positions shown in Figure 1. Flood status 
was assigned from the published Environment Agency indicative floodplain maps. The study sites were selected to represent the widest possible variety of flood status combinations. 
Figure 1 : Location of survey sites

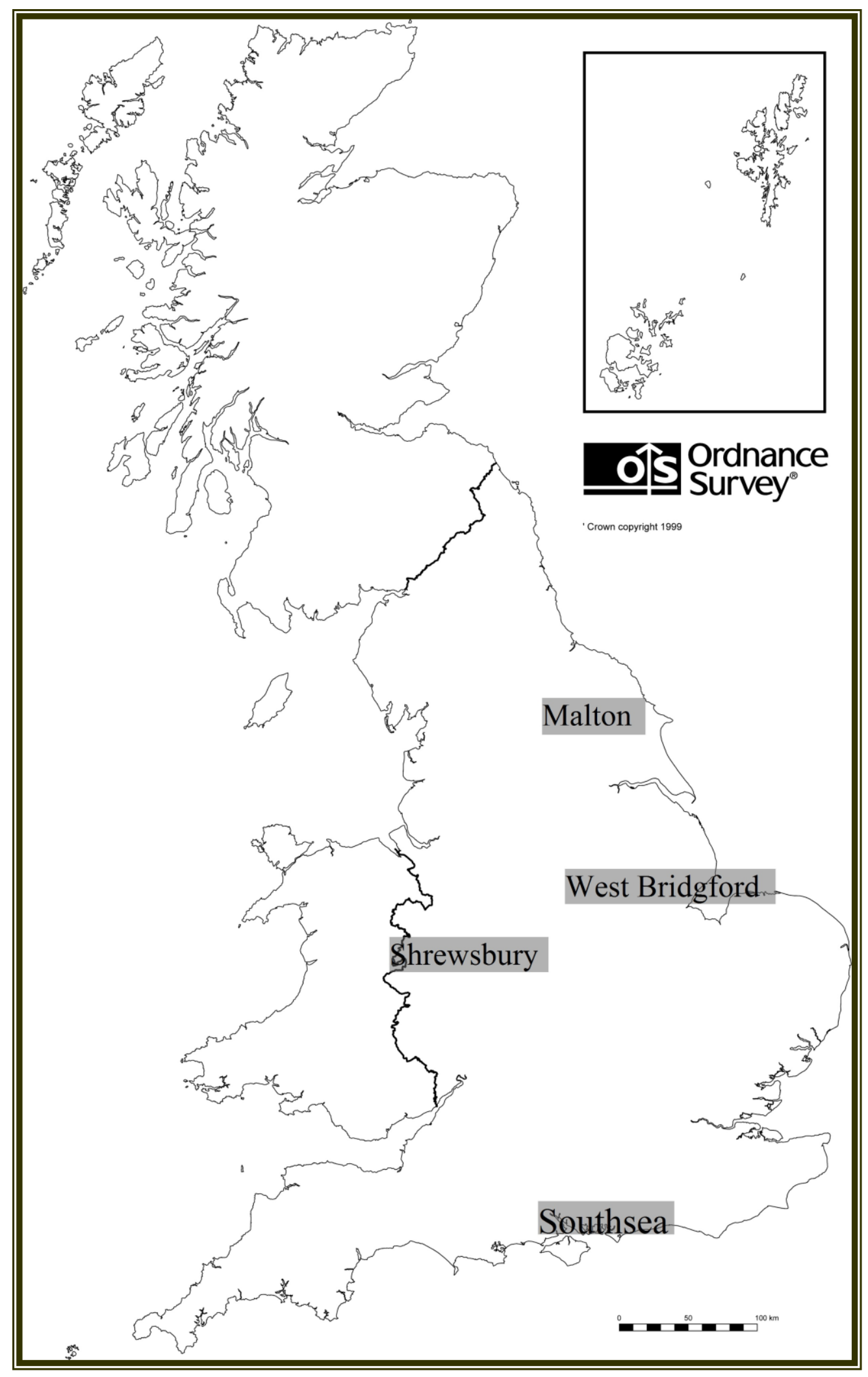




\subsection{Summary of Locations}

Shrewsbury is the county town of Shropshire in the West Midlands of the UK and has a medieval history with many historic buildings situated in the floodplain. Shrewsbury town centre is almost entirely surrounded by the river Severn and during floods access is severely restricted. Shrewsbury has a long history of flooding, and is one of the most frequently flooded places in the UK, with properties in all flood risk categories. Malton and Norton are situated on opposite sides of the river Derwent in North Yorkshire and effectively form one conurbation. Major flood events occurred in Malton and Norton in 1947, 1999, in 2000 during the 2000 event (ARUP, 2006). Many residents in Malton and Norton therefore represent owners of frequent flooded properties which are still at risk.

West Bridgford is an area of Nottingham, a large city in the Midlands, situated within the flood plain of the river Trent. It is a leafy suburb of mainly residential housing with many large properties. Nottingham and West Bridgford experienced floods in 1901, 1910 and 1932; West Bridgford last experienced serious flooding in 1947. Although there was no flooding of West Bridgford itself in 2000, adjacent areas did suffer inundation and therefore awareness of flood risk may be high in this area. Residents of West Bridgford represent owners of property at risk of flooding but with no recent flood history.

Portsmouth is a major port on the south coast of England which is at risk of coastal flooding. Other flooding can occur due to flash flooding during heavy rainfall. The 2000 floods occurred in the Southsea area due to pumping station failure (Clark, 2000) during heavy rainfall. In this population flood claims were lodged by residents at relatively low flood risk.

\subsection{Questionnaire distribution and response rate}

The questionnaires were mailed to 2,100 addresses within one week and a reminder postcard sent to non-respondents three weeks later as the responses were seen to tail off. A nineteen percent response rate was achieved representing 403 returns spread evenly across locations as shown in Error! Reference source not found. and representing householders in all four flood risk categories. The level of responses clearly do not provide a census and with the actual population of the floodplain unknown it is not possible to estimate how well the respondents represented the whole of the floodplain population. However, since responses were obtained from all 
categories of risk profile and flooding history it is possible to draw some specific lessons.

Table 1: Distribution of resposes by location

\begin{tabular}{|c|c|c|c|}
\hline & issued & returned & percent return \\
\hline Shrewsbury & 657 & 144 & 22 \\
\hline Southsea & 575 & 92 & 16 \\
\hline West Bridgford & 277 & 60 & 22 \\
\hline $\begin{array}{l}\text { Malton and } \\
\text { Norton }\end{array}$ & 585 & 107 & 18 \\
\hline Total & 2094 & 403 & 19 \\
\hline
\end{tabular}

\section{Summary of Main Results}

The main results of the survey are themed below into the difficulties encountered during the underwriting negotiation, eventual outcome of search for insurance, the impact of reinstatement, specific issues for new residents, cost of insurance and mitigation issues.

\subsection{Difficulties in Obtaining Insurance}

Respondents to this questionnaire survey described many difficulties in obtaining insurance against flooding. These are summarized in table 2 where it can be seen that $13 \%$ of respondents reported being refused a quote for insurance during the search for cover. More worryingly 3\% (12 respondents) reported being refused renewal due to flood risk. According to the modified statement of principles those outside the significant risk category should not be refused renewal and within the significant category insurers should aim to work with policyholders to maintain cover if possible. Indications from respondents comments are that insurers are not consistently abiding by the renewed agreement at the point of insurance quote. Some suggested that there was confusion due to individual underwriters' lack of experience or knowledge. 
Table 2: Difficulties encountered when requesting quotes for insurance or renewing policy

\begin{tabular}{lll}
\hline Difficulty & $\begin{array}{l}\% \text { of } \\
\text { respondents } \\
\text { reporting } \\
\text { difficulty }\end{array}$ & $\begin{array}{l}\text { Number of } \\
\text { respondents } \\
\text { reporting } \\
\text { difficulty }\end{array}$ \\
\hline A significant increase in premium & 18.7 & 75 \\
Refused a quote due to flood risk & 13.2 & 53 \\
Had to shop around a lot to get an affordable quote & 8.7 & 35 \\
A significant increase in excess & 6.5 & 26 \\
Floods excluded from the policy & 3.7 & 15 \\
Required to provide a letter from the environment agency & 3.2 & 13 \\
Refused a renewal due to flood risk & 3.0 & 12 \\
A significant decrease in premium & 1.7 & 7 \\
Had to use a broker to get an affordable quote & 1.5 & 6 \\
Required to get a survey of flood risk & 0.7 & 3 \\
Had to install resilient fixtures to get cover & 0.2 & 1 \\
Had to install/buy flood protection measures to get cover & 0.0 & 0 \\
\hline \hline
\end{tabular}

In this sample of respondents among those residents of property significantly at risk $5 \%$ (4 Respondents) were refused renewal. Eight residents (2.5\% of respondents) outside the significant category also experienced it. One resident, who had never flooded but been refused renewal, commented

"I told my previous insurer I had never been flooded and the situation had not changed from the year before. They ignored this and said I was now considered to be high risk. The flooding has been as near as $60 \mathrm{~m}$ from back door but, significantly we are on a steepish rise and never felt in danger."

Even so this resident went on to insure with a different insurer at a competitive rate.

Only one respondent reported being required to install resilient features as a condition of cover implying that insurers are not delivering the message about mitigation effectively via the underwriting negotiation. It is possible that competition is impeding the message delivery, if a cheaper policy is available elsewhere then the opportunity to discuss incentives for mitigation may never arise. 
Comparing those previously flooded with those not flooded in Figure 2 reveals that the previously flooded are experiencing more difficulties. For example one third of those previously flooded had experienced refusal to quote for insurance due to flood risk as compared to only $5 \%$ of those not flooded.

Figure 2: Difficulties encountered whilst seeking insurance by flood history

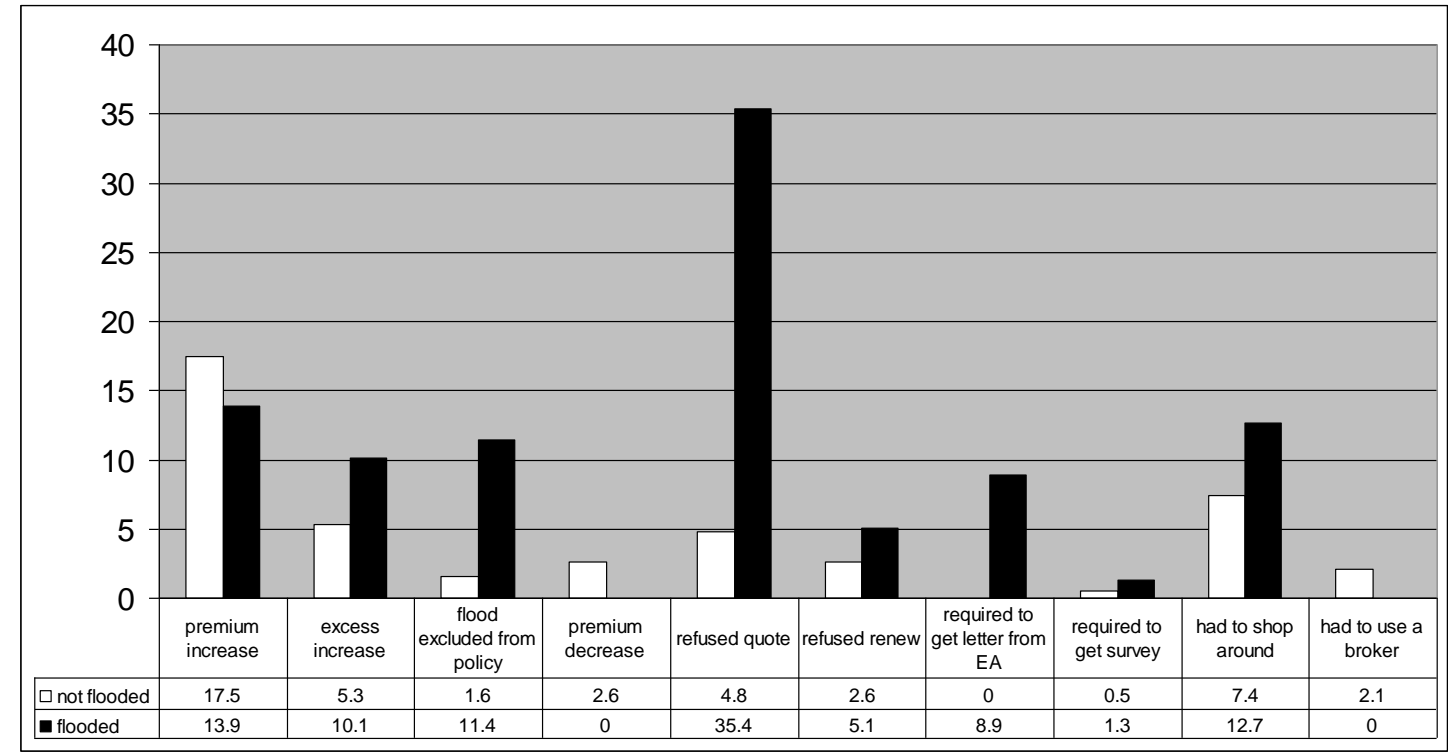

The result was that floodplain respondents tended to stay longer with their insurer and were more likely to be insured with their mortgage lender with possible cost implications. Examining the primary choice mechanism used in selecting a policy reveals that $40 \%$ of floodplain residents used shopping around (brokers, phone and internet searching). When this is compared with the $60 \%$ of residents outside the floodplain who shop around this represents a statistically significant difference in choice strategy. Shopping around has been shown by the AA (2007) to present potential savings of $40 \%$ on premium costs. In this data the increase in premium experienced by those who were not at risk of flood but did not shop around was also $40 \%$ above those who did shop around. This implies that simply by restricting choice, floodplain residents could experience higher premium costs than those outside the floodplain without any impact from risk based premium.

There was also evidence of a subset of floodplain residents pursuing options not considered by the non floodplain population. The largest 5 companies used by nonfloodplain residents represented $55 \%$ of policyholders. Within floodplain residents 
they represented only $30 \%$ and a wider range of alternative companies were represented.

\subsection{Eventual Cover Achieved}

Despite experiencing difficulty whilst seeking insurance it seems that for most residents the final outcome was success. Of the survey, 93\% respondents reported having some kind of insurance. As a comparison, Gaschen et al (1998) estimated for the Swiss Reinsurance company that $95 \%$ of all UK households have buildings insurance. Furthermore, only one respondent ( $0.2 \%$ of respondents) cited flood risk as their reason for being unable to obtain buildings insurance and only three respondents $(0.7 \%)$ reported being unable to obtain contents insurance due to flood risk. This is a reassuring picture and confirms the perception of the ABI (2005c) that their members are not refusing to insure flood risk residents in large numbers.

Another way in which insurance is compromised is by the exclusion of flood damage from the policy. Residents who are unable to gain insurance any other way may accept this exclusion in order to gain cover for other risks such as fire and theft. For a flood risk respondent however this will severely compromise their ability to reinstate a flooded property. Surprisingly $20 \%$ of respondents did not know whether their insurance covered flood risk, one third of these were at moderate or above risk of flooding. This is worrying in that these residents do not seem to be concerned about flooding risk but it is fair to assume that if they have not been told that flooding is excluded from the policy then it will almost certainly be included since inclusion is the default position in the UK. Exclusion of flooding from their policy was suffered by 24 respondents $(6 \%)$. Of these respondents, 6 had previously flooded and a further 9 were at moderate or above risk of flooding.

Excess charges are another way in which cover can be compromised. Large excess over $£ 2,500$ may be regarded as capital at risk by mortgage lenders. In the event of a claim this may be an expense the policyholder cannot afford. In this survey 4 policyholders $(1 \%)$ had to accept excess of $£ 2,500$ or above. One respondent reported being asked to accept a $£ 16,000$ excess but had moved their policy as a result. Perseverance seems to reap rewards in this market; this resident had flooded more than 5 times during a long residence and made more than one flood claim, the last one for $£ 15,000$. Their insurer had then refused contents cover, increased their excess and doubled their premium. But they eventually obtained a policy without exclusions or 
excess at less than half their previous premium elsewhere. Another resident commented

"I purchased house after renting it for 2 years.... Mortgage lender would not arrange insurance.... No internet site would find a quote due to flood risk. All companies I phoned said no, even the company currently insuring the house said no until I found out they were semi-obliged to take me on and I made a fuss to see the supervisor."

In summary, 18 respondents were at moderate or above risk of flooding and had no cover for flood risk. This is $5 \%$ of the total sample and $10 \%$ of those at moderate or above risk of flooding. The majority of these were covered for other risks. This is a cause for concern but far from the blanket ban on insurance that some commentators predicted since $90 \%$ of at-risk residents have achieved full insurance. If the experience of these respondents were repeated nationally then $10 \%$ of property owners at moderate or above risk of flood would hold compromised insurance due to their flood risk status. The ABI estimates that 280,000 homes are at significant risk of flooding; implying 28,000 homes could be at significant risk of flooding and remain uninsured for flood.

\subsection{Impact of Reinstatement}

Those respondents who had experienced flooding were asked to comment on the condition of their property post flood. The vast majority indicated that the reinstatement left their property in the same or better condition than it was before the flood. This must be regarded as a success for the flood repair community that despite well publicised shortcomings within flood repair (Welsh Consumer Council, 1992, Hendy, 2006), the eventual outcome for the victims of the 2000 floods was a well restored home.

\subsection{New Residents}

Those who had recently (in the last 6 years) purchased their property were asked whether they had experienced difficulty in obtaining insurance. One quarter experienced some difficulty in obtaining insurance regardless of flood risk status but of those moderately at risk of flooding over half reported some difficulty with obtaining insurance with $30 \%$ experiencing quite a lot of difficulty. One recent purchaser commented 
"I bought this property in Sep 2005. Company X would not entertain insuring it due to it being in a designated flood risk area but to my knowledge it has never flooded, as despite it being close to a notorious river, it is on a rising slope away from the river and flood water has never reached it.

Company $Y$ had no qualms over insurance, gave me an excellent competitive quote with no reservations so I went with them.

\subsection{Cost of insurance in the floodplain}

For the analysis of insurance rate a subset of respondents was selected. Respondents who held both buildings and contents insurance, flooding was included in the policy and who had provided their insurance cost details were included. This selection mechanism resulted in a sample of 198 questionnaires. An insurance rate was calculated estimating a rebuilding cost from the standard building cost estimator recommended by the $\mathrm{ABI}$ and property details supplied by the responsdents. The median cost of insurance by category is presented in figure 3 . The differences between categories are very small, largely insignificant, and do not reflect the doubling suggested by Crichton (2005) and others. The Kruskall Wallis robust analysis of variance suggests that only with new residents does flood risk status have a significant impact on rates ( $\mathrm{p}$-value $=0.004$ ). This makes some logical sense since, firstly, the ABI statement of principles treats new business differently to established policy holders and, secondly, insurers have no history on which to judge the risk to them of the new property. 
Figure 3: Median rate of insurance by flood status category

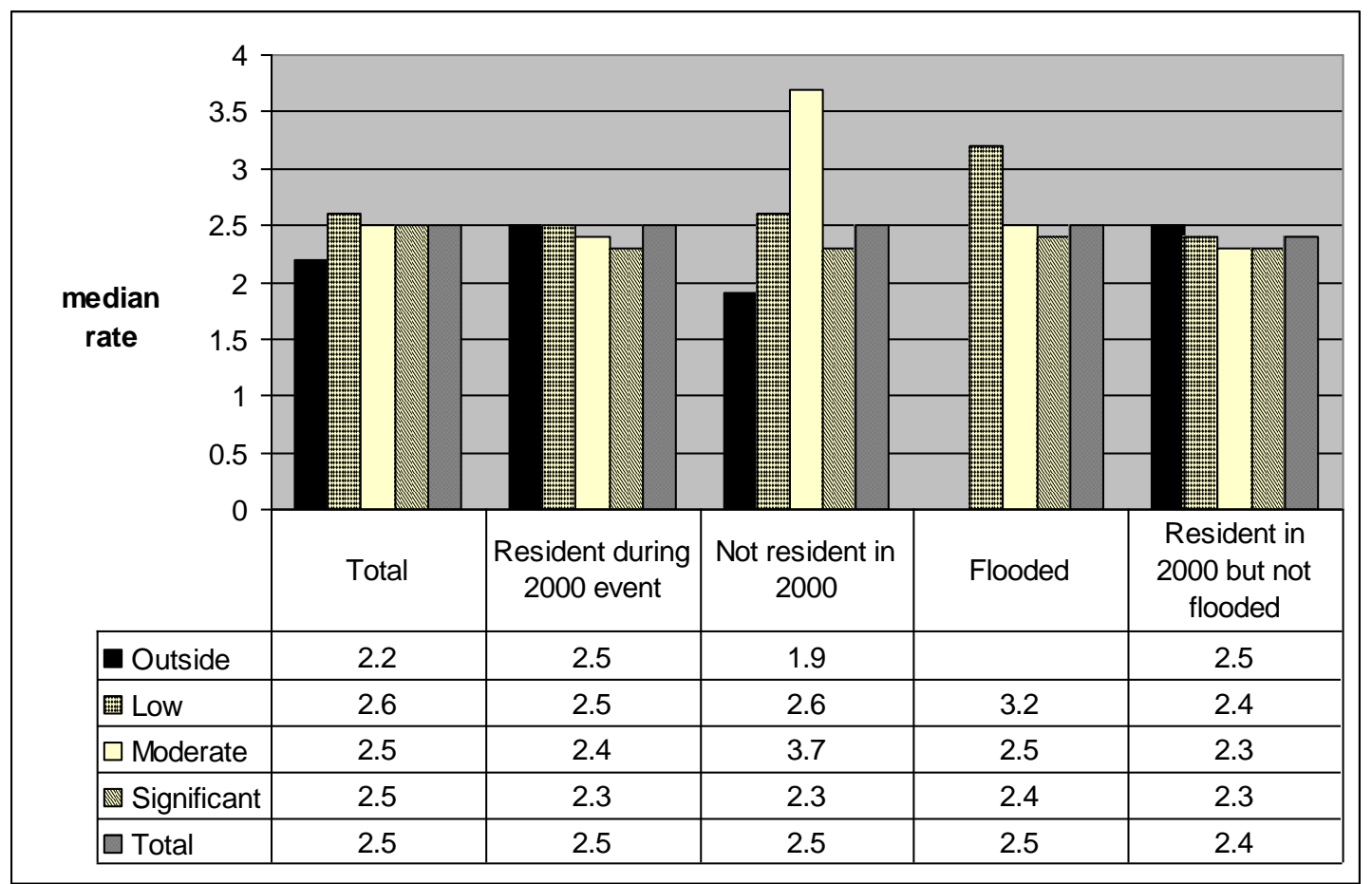

However, variability of the premium paid within the floodplain is much higher than that paid by the non floodplain population. The competitive nature of the insurance market ensures that neighbours can be paying completely different premium rates.

\subsection{Mitigation measures}

It seems from the above analysis that the floodplain resident has neither a legal obligation nor a financial incentive via lower insurance premium to invest in flood mitigation. The perception of their individual risk held by homeowners in the UK is a therefore a key factor in their decision to invest or not. In the wake of recent flooding the generation of awareness of flood risk among residents and the implementation of warning systems has been a target of Environment Agency policy (Hall et al., 2003). This is particularly important in areas which have not recently flooded since false confidence may be generated by the absence of recent inundation.

In sites where flooding has recently occurred the residents may have a better idea about the likelihood of their own property suffering flood damage in a given event than the Environment Agency (Richardson et al., 2003). Comments from the 
questionnaires certainly seemed to suggest that it is the case for some properties in this survey, as indicated in the following extracts.

"Despite being in a flood risk area we are fortunate that our property and those of the others down our cul-de-sac is built on ground which is naturally higher up. We had 2 record breaking floods in a row and I reckon the water would have to rise another 6 foot to get water under the floor boards."

"Before I purchased my house I asked one of my neighbours who has lived here since the 1970s when the house was built if they had been flooded ever, he said no. My house is one of a terrace built by the local council above the flood level. So hopefully it will be OK in a flood."

However there was also some evidence of over reliance upon flood defences, some of which had been constructed since the 2000 event. For example one respondent in Malton who flooded twice in the 2000 event now describes the property as not at risk due to new flood defences despite the designed protection of the defences in Malton being less than the $1.3 \%$ protection level. Roughly half of the comments from Malton residents mentioned the defences. A comparison of respondent-reported flood risk status versus Environment Agency category shows that about a quarter of respondents outside the floodplain considered themselves to be living in a flood risk area while a third of those living in the significant category did not consider themselves at risk of flood.

Awareness of risk at the time of property purchase was also subject to examination. Of those who perceived themselves to be living in a flood risk area, just under half reported that they had been "fully aware" of the risk at purchase. More recent purchasers were more likely to be fully aware than longer residents.

Respondents were asked what mitigation measures they had taken against flood damage. The responses for those who perceived a risk are summarised in figure 4 . Just over half had registered for flood warnings and less than $10 \%$ had taken any of the other measures namely purchasing temporary barriers, installing permanent barriers or installing resilient fixtures and fittings. This finding suggests that the complacency reported in previous studies of at risk populations (Burby, 2001, Brilly and Polic, 2005, Thieken et al., 2006) is repeated in this sample of respondents. Among previously flooded residents also depicted in figure 4, the percentage registering for warnings increases to $73 \%$, the same percentage of flooded residents had removed belongings in advance of the flood. Experiencing a flood had encouraged some residents to install resilient or permanent flood measures, $20 \%$ of 
previously flooded residents have taken other measures, whereas before the flood only $9 \%$ of these had taken other measures. The largest growth was in the installation of resilient fixtures and fittings by an additional 9\%. Although insurance companies do not appear from these survey responses to be insisting on resilient measures or even to be offering premium discounts to those that employ them, the residents that do employ measures believe it helps in obtaining insurance indirectly by reducing claims. As one policyholder put it:

"Our home has been flooded a few times the previous owner made the areas at risk resilient and repaired any damage himself. This means that although a high risk property there has never been a claim for flood damage. The flood we experienced didn't do any damage so we haven't made any claims. This seems to be the secret." 
Figure 4: Mitigation measures taken by residents perceiving a flood risk

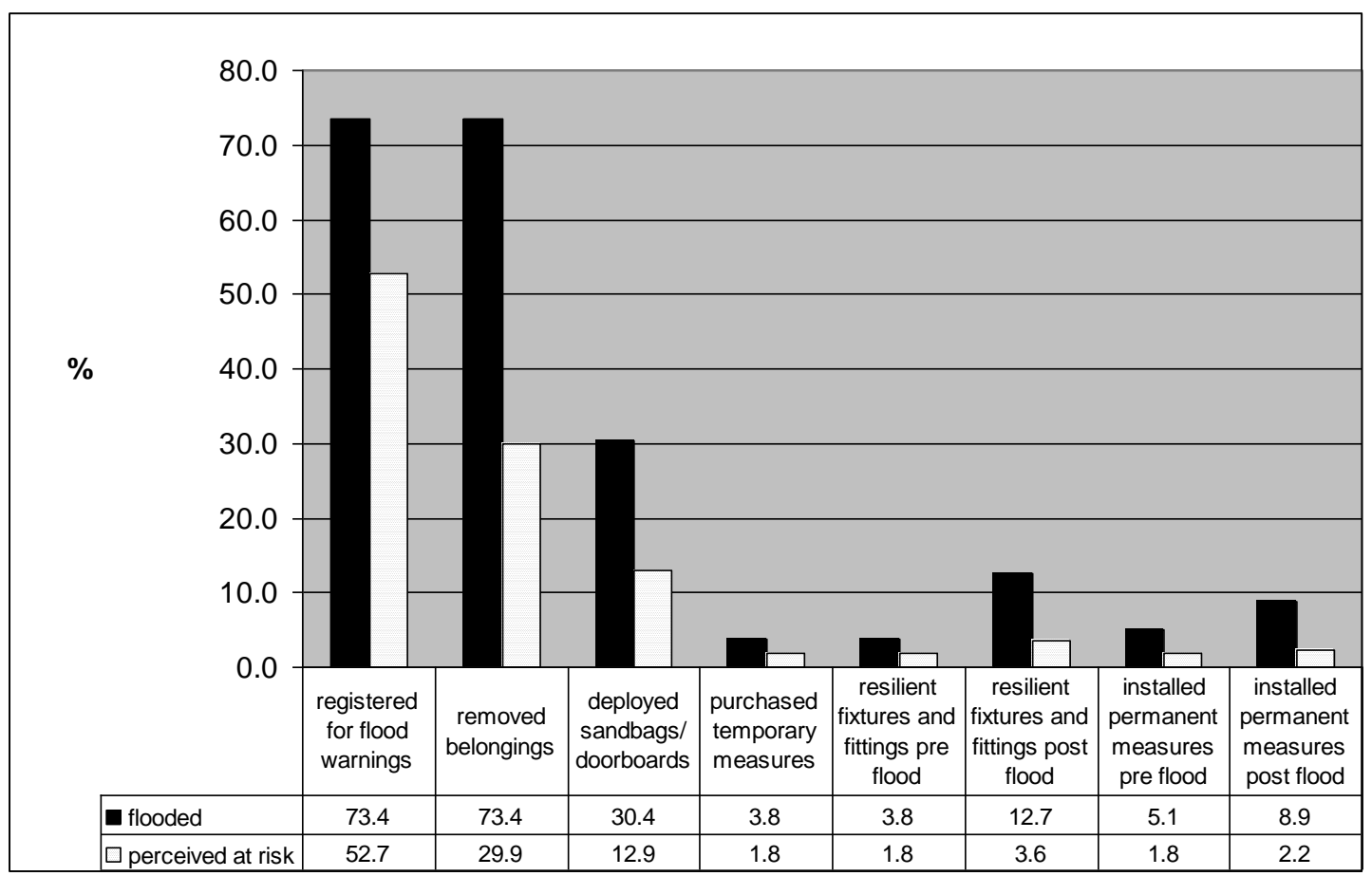

\section{Discussion}

The market for flood insurance in the UK is in a state of mild confusion. The competitive nature of the market ensures that each floodplain resident will have a unique experience. Some flood victims will experience difficulty with renewing their home insurance after a flood event. A larger number will have problems obtaining alternative quotes for insurance and may be forced to remain with their current insurer. New residents may also find difficulty sourcing cover and this may impact on the saleability of a minority of floodplain homes. However the majority of floodplain residents in this survey have never had any difficulties regardless of claims history.

The competitive and fragmented nature of the market has, in some instances, helped floodplain residents gain cover at reasonable rates. Differences between floodplain residents and the rest in the cost of cover are not readily apparent. There is greater variability in the floodplain population but not a higher average rate. While some are trapped with their current provider, clearly the strategy of others is to shop around 
until an affordable rate is achieved. The wide range of companies used by floodplain residents is evidence of this strategy.

This is a reassuring picture in the respect that less than one percent of respondents reported being unable to get insurance cover for either their buildings or their contents. Insurance for some is compromised by the exclusion of flood damage or by high excess charges but the number of policyholders accepting exclusions is also low. On the whole, it would appear, that after a flood the finance and skill is available to restore communities to pre flood condition. Given that flood repair is often an expense property owners are ill prepared for and that more than half of floodplain residents were not fully aware of flood risk status at purchase it would seem undesirable to move far from this status quo.

However the concerns of the insurer and the wider community have still to be addressed. If the majority of floodplain residents still have flood cover then the majority of flood damage expenses are still the responsibility of the insurer. Insurers can put political pressure on governments to increase spending on flood defences but they lack leverage with policyholders unless they can act in a concerted manner. This survey found no evidence that insurers are requiring or even encouraging floodplain residents to take partial responsibility for damage management via conditional cover or premium discounts. This begs the question as to why insurers are not taking these steps and this may be due to competition and lack of information.

An encouraging finding was that some damage avoidance actions are being adopted by floodplain residents. Just over half of residents perceiving themselves in a flood risk environment had registered for flood warnings. This rose to three quarters of those previously flooded. Belongings were commonly removed during a second flood.

However, the strategy pursued by floodplain residents of switching insurers undermines any attempt by individual insurers to further encourage flood avoidance or mitigation. While insurance remains available for high risk property at standard rates from even a minority of insurers there is little incentive for homeowners to expend their limited resources on flood mitigation measures unless they can perceive advantages other than financial for doing so. The evidence from this survey shows that a majority of flooded residents take those mitigating actions which are of least cost to them and will preserve personal items. More expensive actions are taken by a very small minority. Those residents who are at risk of flood but have never flooded 
are even less likely to recognise the need to protect themselves. Strong government guidance or leadership by the ABI and major insurers is needed here if significant change is to ensue.

If large future flood damage costs are to be avoided, adaptation to flood risk is necessary but difficult to achieve. The insurance market could be a useful tool in encouraging adaptation if all players are well enough informed and can therefore act in a consistent fashion. The awarding of Government grants for flood protection could be a way forward if the benefits of mitigation were assured. Two sources of important information need to be improved in quality and accessibility if this greater good is to be realized.

Despite recent improvements in flood risk mapping the Environment Agency indicative floodplain maps were not designed to fulfil the purpose for which they are now being used and an alternative, preferably freely available, classification system would bring clarity to the situation. Greater understanding of the cost benefit ratios of individual mitigation measures would be useful in persuading all stakeholders of the desirability or not of these measures.

\section{List of References}

AA (2007) Insurance Premium Index. Automobile Association.

ABI (2002) ABI statement of principles on the provision of flooding insurance. Association of British Insurers.

ABI (2005a) ABI statement of principles on the provision of flood insurance- updated version, November 2005. Association of British Insurers.

ABI (2005b) Financial risks of climate change, Association of British Insurance.

ABI (2005c) Revisiting the partnership: five years on from autumn 2000 - October 2005 anniversary report. Association of British Insurers.

ABI (2005d) The social value of general insurance. Association of British Insurers.

ARNELL, N. W., CLARK, M. J. \& GURNELL, A. M. (1984) Flood insurance and extreme events: the role of crisis in prompting changes in British institutional response to flood hazard. Applied Geography, 4, 167-181.

ARUP (2006) Northeast Yorkshire strategic flood risk assessment. Final report for Ryedale Disctict Council, Scarborough Borough Council and North York Moors National Park Authority. ARUP.

BRILLY, M. \& POLIC, M. (2005) Public perception of flood risks, flood forecasting and mitigation. Natural Hazards and Earth System Sciences, 5, 345-355.

BROWNE, M. J. \& HOYT, R. E. (2000) The demand for flood insurance: empirical evidence. Journal of Risk and Uncertainty, 20, 291-306.

BURBY, R. J. (2001) Flood insurance and floodplain management : The US experience. Global Environmental Change Part B: Environmental Hazards, 3, 111 - 122. 
CLARK, C. (2000) The great morass reappears, Southsea flood. Portsmouth Society News.

CLARK, M. J., PRIEST, S. J., TREBY, E. J. \& CRICHTON, D. (2002) Insurance and UK floods a strategic reassessment. report of the Tsunami project. Universities of Southampton, Bournemouth and Middlesex.

CRICHTON, D. (2005) Flood risk and insurance in England and Wales : are there lessons to be learned from Scotland? Technical Report. Benfield Hazard Research Centre.

DEY, I. (2006) Insurers threaten to withdraw flood cover. Vulnerable properties will be 'uninsurable' if Defra cuts pounds $15 \mathrm{~m}$ from flood defence budget. The Sunday Telegraph. Aug. 20th 2006 ed. London.

DLUGOLECKI, A. (2004) A changing climate for insurance : a summary report for chief executives and policymakers. Association of British Insurers.

DOWNES, S. (2005) Floods: insurers cut up rough. The Sunday Telegraph. 6th Nov 2005 ed. London.

EA (2006) Environment Agency Flood Map. Environment Agency.

EA/DEFRA (2005) The appraisal of human related intangible impacts of flooding. Technical report. Environment Agency / Department of Food and Rural Affairs.

EHRLICH, I. \& BECKER, G. S. (1972) Market insurance, self-insurance and selfprotection. Journal of political economy, 80, 623-648.

ENVIRONMENT AGENCY (2001) Lessons learned Autumn 2000 floods. Environment Agency.

ENVIRONMENT AGENCY (2004) What does the foresight report show? Environment Agency.

FLEMING, G. (2001) Learning to live with rivers. The Institution of Civil Engineers.

GASCHEN, S., HAUSMANN, P., MENZINGER, I. \& SCHAAD, W. (1998) Floods - an insurable risk? A market survey. Swiss Re.

GREEN, C. \& PENNING-ROWSELL, E. (2004) Flood insurance and government: "parasitic" and "symbiotic" relations. The Geneva Papers on risk and insurance, 29, 518-539.

GRUNTFEST, E. (1995) Long term social and economic impacts of extreme floods. US - Italy research workshop on the Hydrometeorology, impacts, and management of extreme floods. Perugia (Italy).

HAJAT, S., EBI, K. L., KOVATS, S., MENNE, B., EDWARDS, S. \& HAINES, A. (2003) The human health consequences of flooding in Europe and the implications for public health: a review of the evidence. Applied Environmental Science and Public Health, 1, 13-21.

HALl, J. W., MEADOWCROFT, I. C., SAYERS, P., B. \& BRAMLEY, M. E. (2003) Integrated Flood Risk Management in England and Wales. Natural Hazards Review, 4, 126-135.

HENDY, P. (2006) Carlisle events - the victims perspective. floodrepair network workshop on identification and dissemination of good practice. Telford, (UK).

HUBER, M. (2004) Insurability and regulatory reform: is the English flood insurance regime able to adapt to climate change. The Geneva Papers on risk and insurance, 29, 169-182.

JONES, R. (2003) Weather: homeowners struggle to find insurance cover. The Guardian. 3rd Jan 2003 ed. Manchester. 
KRIESEL, W. \& LANDRY, C. (2004) Participation in the National Flood Insurance Program: an empirical analysis for coastal properties. The Journal of Risk and Insurance, 71, 405-420.

KUNREUTHER, H. (1974) Disaster insurance: a tool for hazard mitigation. The Journal of Risk and Insurance, 41, 288-303.

LAMOND, J., PROVERBS, D., ANTWI, A. \& GAMESON, R. (2006) Flood insurance in the UK: how does the changing market affect the availability and cost to homeowners. Building Education and Research Conference. Hong Kong.

MACDONALD, D. N., MURDOCH, J. C. \& WHITE, H. L. (1987) Uncertain hazards, insurance and consumer choice: evidence from housing markets. Land Economics, 63, 362 - 371.

RICHARDSON, J., REILLY, J. \& JONES, P. J. S. (2003) Community and public participation: risk communication and improving decision making in flood and coastal defence. DEFRA flood and coastal management conference. Keele University.

SAMWINGA, V., PROVERBS, D. \& HOMAN, J. (2004) Exploring the experience of UK homeowners in flood disasters. International construction research conference. Royal Institute of Chartered Surveyors.

SHILliNG, J. D., SIRMANS, C. F. \& BENJAMIN, J. D. (1989) Flood insurance, wealth redistribution and urban property values. Journal of Urban Economics, 26, 43-53.

SOETANTO, R., PROVERBS, D. \& NICHOLAS, J. (2002) Benchmarking domestic property flood damage assessment. University of Wolverhampton report for LLoyds TSB insurance.

STEVENSON, R. (2002) Esure axes insurance for property at risk of flooding. Money Marketing. June 20th 2002 ed.

THIEKEN, A., H., PETROW, T., KREIBICH, H. \& MERZ, B. (2006) Insurability and mitigation of flood losses in private households in Germany. Risk Analysis, 26, 1-13.

WARWICKSHIRE TRADING STANDARDS (1998) A Flood of Claims. Warwickshire Trading Standards Department.

WELSH CONSUMER COUNCIL (1992) In deep water - A study of consumer problems in Towyn and Kinmel Bay after the 1990 floods. Cardiff, Welsh Consumer Council.

WHICH? (2005) Buildings insurance: the cost of claiming. The Consumer Association. 
